\title{
FABRICATION AND PERFORMANCE OF SOLAR PARABOLIC TROUGH CONCENTRATOR WITH AND WITHOUT COATING ON RECEIVER TUBE
}

\section{ARUN GEORGE, ER. EARNEST VINAY PRAKASH \& AJEET KUMAR RAI}

Department of Mechanical Engineering, SIET, Sam Higginbottom University of

Agriculture Technology and Sciences, Allahbad (U.P), India

\begin{abstract}
This paper is concerned with design, fabrication and experimental study to evaluate and compare the performance of two different PTCs, to produce hot water by coating and without coating black paint on receiver pipe. In PTC-1, the receiver pipe is without coating of black paint and PTC-2 receiver pipe is coated with black paint. Receiver pipe in both the PTCs are made of aluminium. Reflector materials used in both the PTCs are made of stainless steel. Rim angle and aperture area for both the concentrators are $90^{\circ}$ and $2.131 \mathrm{~m}^{2}$. Concentration ratios for both the concentrators are 10.91. Maximum instantaneous thermal efficiency was obtained as $21.34 \%$ when solar intensity was 260 W/m ${ }^{2}$ by the concentrator which has its receiver pipe coated by the black paint.

KEYWORDS: Solar Parabolic Trough Collector (PTC), Reflector, Receiver, Maximum Thermal Efficiency, Maximum Temperature, Fabrication \& Coating
\end{abstract}

Received: Jul 15, 2017; Accepted: Aug 06, 2017; Published: Aug 21, 2017; Paper Id.: IJMPERDAUG201743

\section{INTRODUCTION}

Parabolic trough concentrator is a solar concentrator technology that converts solar beam radiation into thermal energy. PTC mainly consists of cylindrical parabolic reflector and a receiver pipe made of metal placed at the focal plane of the parabolic reflector. The heat transferring fluid flows through the receiver tube gets heated and then carries the heat along with it. These types of concentrator's are being used since many years. There are many parameters responsible for designing of the concentrator like aperture diameter, rim angle, absorber size and shape, absorber and parabolic reflector materials. Absorber tube can be made from Galvanized Iron, aluminium, steel or copper. Parabolic reflector can be made from anodized, stainless steel, acrylic mirror, aluminium or curved silver glass mirror. Parabolic reflector is fixed on light weight and strong structure. Generally, PTC are oriented in eastwest, north-south or polar directions. The east-west and north-south directions is simple and easy way to be oriented, it has higher incidence angle cosine losses. The polar configuration intercepts more solar radiation per unit area and gives the best efficiency.

\section{DESIGN CONSIDERATION}

The present PTC has been designed and fabricated with the following characteristics keeping in mind; easily constructible, strong and reliable structure, light weight and less costly. Parabolic reflector is made of stainless steel, which is $2.007 \mathrm{~m}$ long, $1.218 \mathrm{~m}$ wide and $0.319 \mathrm{~mm}$ thickness. Reflectivity of the stainless steel mirror is $64.9 \%$ of sunlight.

Absorber tube is made of aluminium which is $2.13 \mathrm{~m}$ long and outer diameter is $0.03 \mathrm{~m}$. The reflector 
sheet was installed on the parabolic shape structure of the frame on the stand. PTC-1 was installed with receiver pipe without coating and PTC-2 receiver pipe was coated with Hughson Black paint H322 whose solar absorption rate is 0.96 and surface emissivity rate is 0.86 .

\section{Calculation for the Parabolic End}

To determine the dimension of the PTC the following parameters are considered:

Rim Angle $(\Psi)=90^{\circ}$

Width $(\mathrm{S})=1.218 \mathrm{~m}$

Width of the aperture $\left(\mathrm{W}_{\mathrm{a}}\right)$ :

$\mathrm{W}_{\mathrm{a}}=2 \mathrm{~S} \tan (\Psi / 2) /\{\sec (\Psi / 2) \times \tan (\Psi / 2)+\operatorname{In}(\sec (\Psi / 2)+\tan (\Psi / 2))\}=1062.25 \mathrm{~mm}$ or $1.0622 \mathrm{~m}$

Focal Length of Parabola (F):

$\mathrm{F}=\mathrm{W}_{\mathrm{a}} / 4 \tan (\Psi / 2)=265.56 \mathrm{~mm}$ or $0.2655 \mathrm{~m}$

Equation of parabola $\left(\mathrm{X}^{2}\right)$ :

$\mathrm{X}^{2}=4 \times \mathrm{F} \times \mathrm{Y}=1062.24 \mathrm{Y}$

Geometrical concentration ratio $(\mathrm{C})$ :

$\mathrm{C}=\mathrm{W}_{\mathrm{a}} / \pi \mathrm{D}_{\mathrm{o}}=10.91$

Table 1: Specifications of PTC

\begin{tabular}{|l|c|c|}
\hline \multicolumn{1}{|c|}{ P.T.C Name } & PTC- (1) & PTC- (2) \\
\hline Reflector Material & Stainless Steel & Stainless Steel \\
\hline Focal length $(\mathrm{F})$ & $0.265 \mathrm{~m}$ & $0.265 \mathrm{~m}$ \\
\hline Rim angle $(\Psi)$ & $90^{\circ}$ & $90^{\circ}$ \\
\hline Aperture width $\left(\mathrm{W}_{\mathrm{a}}\right)$ & $1.0622 \mathrm{~m}$ & $0.031 \mathrm{~m}$ \\
\hline Diameter of receiver tube $\left(\mathrm{D}_{\mathrm{o}}\right)$ & $0.031 \mathrm{~m}$ & $2.007 \mathrm{~m}$ \\
\hline Length of parabola $(\mathrm{L})$ & $2.007 \mathrm{~m}$ & $2.132 \mathrm{~m}^{2}$ \\
\hline Effective aperture area $\left(\mathrm{A}_{\mathrm{a}}\right)$ & $2.132 \mathrm{~m}^{2}$ & 10.91 \\
\hline Concentration Ratio $(\mathrm{c})$ & 10.91 & 0.63 \\
\hline Reflectivity of collector $(\rho)$ & 0.63 & 0.8 \\
\hline Absorptivity of receiver tube $(\alpha)$ & 0.8 & 2.13 \\
\hline Length of receiver tube $\left(\mathrm{L}_{\mathrm{abs}}\right)$ & 2.13 & 0.305 mm \\
\hline Receiver material & Aluminum pipe without coating & Aluminum pipe coated with black paint \\
\hline Thickness of reflector material & $0.305 \mathrm{~mm}$ & \\
\hline
\end{tabular}

\section{FABRICATION OF PTC}

The construction of Parabolic Trough Concentrator is very simple. It consists of a parabolic trough collector, an absorber or receiver tube, supporting frame, fluid storage tank. The detailed description is as follows:

\section{Parabolic Trough}

The proposed trough collector consists of stainless steel sheet of $2.006 \mathrm{~m}$ long, $1.218 \mathrm{~m}$ wide and $0.319 \mathrm{~mm}$ thickness, which has undergone a careful deformation process to bring it into parabola shape. The aperture width of trough is $1.062 \mathrm{~m}$, focal length is $0.264 \mathrm{~m}$ and aperture area of the reflecting surface is $2.132 \mathrm{~m}^{2}$. 


\section{Receiver Tube}

PTC is designed to heat water at atmospheric temperature and pressure. Receiver pipe is made of aluminium, which is $2.12 \mathrm{~m}$ long and outer diameter is $0.03 \mathrm{~m}$. The pipe is placed at the focal line of the collector. Circular shape of the tube is most efficient, as it covers less area to avoid shading of the reflector, and it is easily available.

\section{Collector Support Frame}

For a reliable strength and accuracy, the frame is made is designed with rigid iron strips. The structural frame is supported to the rotation axis of the parabolic reflector surface. For tracking sun, it is rotated at horizontal axis. The frame is manual tracking.

\section{EXPERIMENTAL SETUP}

The experimental setup consists of two Parabolic Trough Concentrator. Both the PTCs have a water storage tank of 15 liters capacity and parabolic reflector is made of stainless steel. In PTC-1, the receiver pipe is made of aluminium without coating and in PTC-2; the receiver pipe is made of aluminium with coating of black paint. The setup is oriented in North South direction. The water tank is placed above the level of receiver pipe to allow the natural flow of fluid from the tank to the receiver pipe without the help of a pump. The water inlet and outlet temperature, ambient temperature, reflector surface temperature, solar radiation intensity, wind velocity and receiver pipe inlet/middle/outlet temperature are measured and kept a record of it during the experiment. The experiment was performed in the month of May and June 2017 , SHUATS, Allahabad (U.P).

\section{TESTING}

Test started at 10 a.m. Water from the tank is allowed to flow to receiver pipe. Temperature of water is measured after every 30 minutes. At every 15 minutes it was ensured that incoming beam radiation should fall at focal line of the parabola by manual tracking.

\section{CASE-1}

For PTC-1 having receiver pipe without coating

Date: $29 / 05 / 2017$

Climatic Condition: Hot

Minimum Ambient Temperature: $35.6{ }^{\circ} \mathrm{C}$ at 10 a.m

Maximum Ambient Temperature: $43.2^{\circ} \mathrm{C}$ at 1 p.m

Table 2: Analyzes For PTC-1

\begin{tabular}{|l|l|l|l|l|l|l|}
\hline S. No. & Time & $\begin{array}{c}\text { Inlet } \\
\text { Temp. } \\
\left(\mathbf{T}_{\mathbf{1}}\right)\end{array}$ & $\begin{array}{c}\text { Outlet } \\
\mathbf{T e m p .} \\
\left(\mathbf{T}_{\mathbf{6}}\right)\end{array}$ & $\begin{array}{c}\text { S.I. } \\
\left(\mathbf{H}_{\mathbf{b}}\right)\end{array}$ & $\begin{array}{c}\text { Wind } \\
\text { Speed } \\
\left(\mathbf{W}_{\mathbf{v}}\right)\end{array}$ & $\begin{array}{c}\text { Ambient } \\
\text { Temp. } \\
\left(\mathbf{T}_{\mathbf{a}} \mathbf{)}\right.\end{array}$ \\
\hline 1 & $10.00 \mathrm{AM}$ & 33.5 & 46.5 & 550 & 1.6 & 36.1 \\
\hline 2 & $10.30 \mathrm{AM}$ & 33.8 & 52.5 & 850 & 2.6 & 38 \\
\hline 3 & $11.00 \mathrm{AM}$ & 34 & 53.1 & 750 & 3.1 & 39.6 \\
\hline 4 & $11.30 \mathrm{AM}$ & 34.3 & 55.2 & 900 & 2.7 & 41.7 \\
\hline 5 & $12.00 \mathrm{PM}$ & 35.1 & 57.9 & 950 & 2.5 & 42.6 \\
\hline 6 & $12.30 \mathrm{PM}$ & 35.4 & 59.8 & 970 & 2.8 & 42.9 \\
\hline
\end{tabular}




\begin{tabular}{|l|l|l|l|l|l|l|}
\hline 7 & 01.00 PM & 35.6 & 59.3 & 780 & 1.8 & 41.8 \\
\hline 8 & 01.30 PM & 34.4 & 57.6 & 720 & 2.5 & 41.6 \\
\hline 9 & 02.00 PM & 34.1 & 55.8 & 610 & 2.7 & 41.4 \\
\hline 10 & 02.30 PM & 34.5 & 54.7 & 510 & 2.1 & 38.9 \\
\hline 11 & 03.00 PM & 34.4 & 53.4 & 380 & 1.8 & 38.6 \\
\hline 12 & 03.30 PM & 34.2 & 52 & 360 & 2.1 & 38.3 \\
\hline 13 & 04.00 PM & 34 & 49.5 & 290 & 1.8 & 38 \\
\hline 14 & 04.30 PM & 34.1 & 49.3 & 260 & 1.9 & 37.6 \\
\hline
\end{tabular}

Calculation for Thermal Efficiency

$\eta=Q \times 100 /\left(A_{a} \times H_{b} \times \rho \times R_{b}\right)$

Where,

$\mathrm{Q}=$ Net useful heat gained by the fluid (watt) $=\mathrm{m} \mathrm{C}_{\mathrm{p}}(\mathrm{T} 6-\mathrm{T} 1)$

$\mathrm{m}=$ mass flow rate of fluid $(\mathrm{Kg} / \mathrm{sec})$

$\mathrm{C}_{\mathrm{p}}=$ specific heat of fluid $=4180 \mathrm{~J} / \mathrm{Kg} \mathrm{K}$ for water

$\mathrm{T}_{6}=$ Maximum temperature attained by fluid $\left({ }^{\circ} \mathrm{C}\right)$

$\mathrm{T}_{1}=$ Initial temperature of fluid $\left({ }^{\circ} \mathrm{C}\right)$

$\mathrm{A}_{\mathrm{a}}=$ Aperture area $\left(\mathrm{m}^{2}\right)$

$\mathrm{H}_{\mathrm{b}}=$ Solar Intensity $\left(\mathrm{W} / \mathrm{m}^{2}\right)$

$\rho=$ Reflectivity of collector materials

$\mathrm{R}_{\mathrm{b}}=$ Tilt Factor for beam radiation (assuming collector is always normal to radiation) $=1$

Mass flow rate $(\mathrm{m})=3.16 \mathrm{~kg} / \mathrm{hrs}$

$=.000878 \mathrm{~kg} / \mathrm{sec}$

For,

Initial Temperature $\left(\mathrm{T}_{1}\right)=34.1{ }^{\circ} \mathrm{C}$ at 04.30 p.m

Maximum Temperature $\left(\mathrm{T}_{6}\right)=49.3{ }^{\circ} \mathrm{C}$ at 04.30 p.m

$\mathrm{Q}=\mathrm{m} \mathrm{C}_{\mathrm{p}}\left(\mathrm{T}_{6}-\mathrm{T}_{1}\right)=55.78461 \mathrm{~W}$

Efficiency $(\eta)=Q \times 100 /\left(A_{a} \times H_{b} \times \rho \times R_{b}\right)$

$=15.98 \%$

\section{CASE-2}

For PTC-2 having receiver pipe with coating

Date: $29 / 05 / 2017$

Climatic Condition: Hot

Minimum Ambient Temperature: $35.6{ }^{\circ} \mathrm{C}$ at 10 a.m 
Maximum Ambient Temperature: $43.2{ }^{\circ} \mathrm{C}$ at 1 p.m

Table 3: Analyzes for PTC-2

\begin{tabular}{|c|c|c|c|c|c|c|}
\hline S. No. & Time & $\begin{array}{c}\text { Inlet } \\
\text { Temp. }\left(\mathrm{T}_{1}\right)\end{array}$ & $\begin{array}{c}\text { Outlet } \\
\text { Temp. }\left(\mathbf{T}_{6}\right)\end{array}$ & $\begin{array}{l}\text { S.I. } \\
\left(H_{b}\right)\end{array}$ & $\begin{array}{c}\text { Wind } \\
\operatorname{Speed}\left(\mathbf{W}_{v}\right)\end{array}$ & $\begin{array}{c}\text { Ambient } \\
\text { Temp. }\left(\mathrm{T}_{\mathrm{a}}\right)\end{array}$ \\
\hline 1 & $10.00 \mathrm{AM}$ & 34.8 & 50.4 & 550 & 1.6 & 36.1 \\
\hline 2 & $10.30 \mathrm{AM}$ & 34.8 & 59.9 & 850 & 2.6 & 38 \\
\hline 3 & $11.00 \mathrm{AM}$ & 35 & 59 & 750 & 3.1 & 39.6 \\
\hline 4 & $11.30 \mathrm{AM}$ & 34.1 & 63 & 900 & 2.7 & 41.7 \\
\hline 5 & 12.00 PM & 33 & 64.9 & 950 & 2.5 & 42.6 \\
\hline 6 & $12.30 \mathrm{PM}$ & 33.7 & 65.7 & 970 & 2.8 & 42.9 \\
\hline 7 & $01.00 \mathrm{PM}$ & 35.6 & 66.1 & 780 & 1.8 & 41.8 \\
\hline 8 & $01.30 \mathrm{PM}$ & 35.8 & 68.7 & 720 & 2.5 & 41.6 \\
\hline 9 & $02.00 \mathrm{PM}$ & 34.1 & 61.4 & 610 & 2.7 & 41.4 \\
\hline 10 & $02.30 \mathrm{PM}$ & 34.5 & 59.8 & 510 & 2.1 & 38.9 \\
\hline 11 & 03.00 PM & 34.4 & 59.6 & 380 & 1.8 & 38.6 \\
\hline 12 & $03.30 \mathrm{PM}$ & 34.2 & 58.9 & 360 & 2.1 & 38.3 \\
\hline 13 & $04.00 \mathrm{PM}$ & 34 & 54.9 & 290 & 1.8 & 38 \\
\hline 14 & $04.30 \mathrm{PM}$ & 34.1 & 54.4 & 260 & 1.9 & 37.6 \\
\hline
\end{tabular}

Calculation for Thermal Efficiency

$\eta=Q \times 100 /\left(A_{a} \times H_{b} \times \rho \times R_{b}\right)$

Where,

$\mathrm{Q}=$ Net useful heat gained by the fluid $($ watt $)=\mathrm{m} \mathrm{C}_{\mathrm{p}}(\mathrm{T} 6-\mathrm{T} 1)$

Mass flow rate $(\mathrm{m})=3.16 \mathrm{~kg} / \mathrm{hrs}=.000878 \mathrm{~kg} / \mathrm{sec}$

For,

Initial Temperature $\left(\mathrm{T}_{1}\right)=34.1{ }^{\circ} \mathrm{C}$ at 04.30 p.m

Maximum Temperature $\left(\mathrm{T}_{6}\right)=54.4^{\circ} \mathrm{C}$ at 04.30 p.m

$\mathrm{Q}=\mathrm{m} \mathrm{C}_{\mathrm{p}}\left(\mathrm{T}_{6}-\mathrm{T}_{1}\right)=74.50181 \mathrm{~W}$

Efficiency $(\eta)=Q \times 100 /\left(A_{a} \times H_{b} \times \rho \times R_{b}\right)=21.34 \%$

\section{RESULTS AND DISCUSSIONS}

Readings were recorded in the month of May and June 2017 at SHUATS, Allahabad, Uttar Pradesh, India.

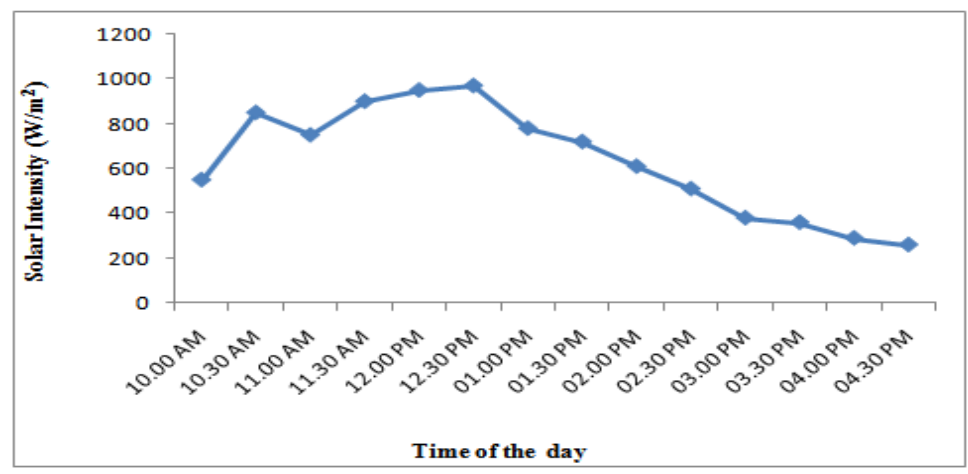

Figure 1: Graph of Solar Intensity with Time 
Figure 1 shows variation in solar intensity with respect to time. Maximum intensity is $970 \mathrm{~W} / \mathrm{m}^{2}$ at 12.30 p.m.

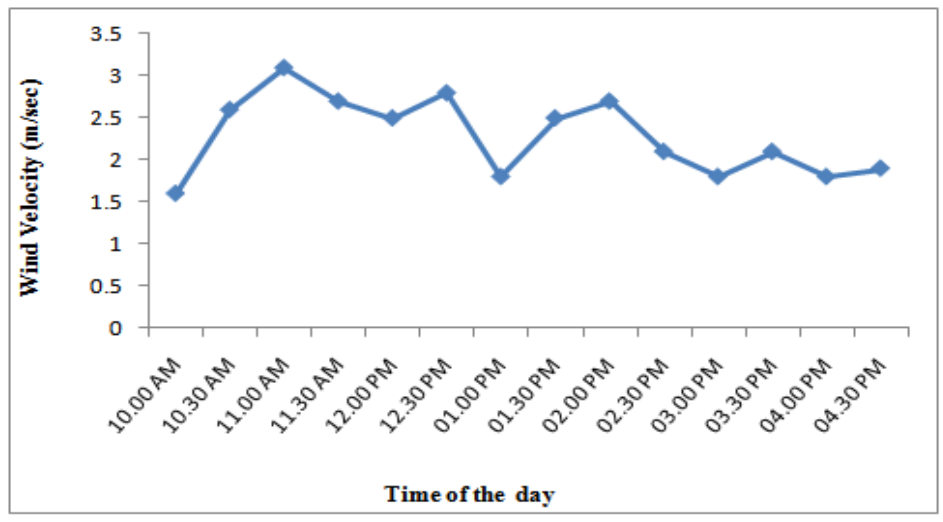

Figure 2: Graph of Wind Velocity with Time

Figure 2 shows variation in wind speed with respect to time, which is normal.

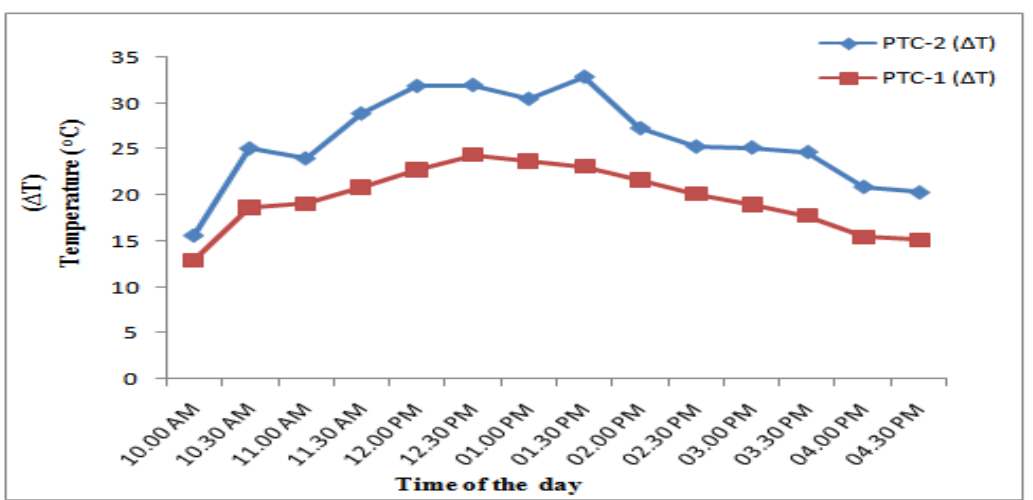

Figure 3: Graph of Temperature Difference with Time

Figure 3 shows the variation in temperature difference between inlet and outlet temperature with respect to time. For PTC-1, maximum temperature difference is $24.4{ }^{\circ} \mathrm{C}$ at $12.30 \mathrm{p} . \mathrm{m}$. and minimum temperature difference is $13{ }^{\circ} \mathrm{C}$ at 10.00 a.m. For PTC-2 maximum temperature difference is $32.9^{\circ} \mathrm{C}$ at $01.30 \mathrm{p} . \mathrm{m}$. and minimum temperature difference is $15.6^{\circ} \mathrm{C}$ at 10.00 a.m.

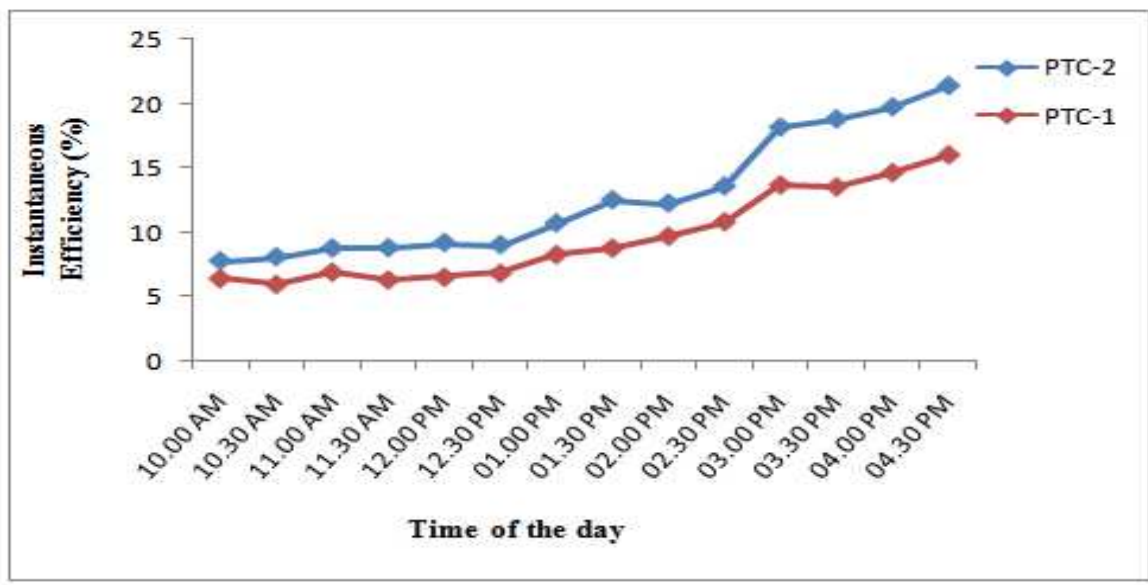

Figure 4: Graph of Thermal Efficiency with Time of PTC-1 and PTC-2 
Figure 4 shows the variation in instant thermal efficiency of both the PTCs with respect to time of the day. Instant thermal efficiency of PTC-1 is $15.98 \%$ and of PTC-2 is $21.34 \%$ at 04.30 p.m.

\section{CONCLUSIONS}

Comparing the performance of both PTC-1 and PTC-2 on the basis of data recorded during testing and evaluating the data in the form of graphs and tables, it is clear that performance and efficiency of PTC-2 is higher than PTC-1. Maximum temperature of outlet water obtained by the PTC-2 is $68.7{ }^{\circ} \mathrm{C}$ due to the coating of black paint on the surface of the receiver pipe. Construction of the PTC setup is low, and it is a simple technology with exhaustible source of energy.

\section{REFERENCES}

1. “Solar collectors", Science Direct, Elsevier, Solar Energy, Volume 62, Issue 6, Pages395-406.

2. Almanza R. \& Lentz A. (1998) "Electricity production at low powers by direct steam generation with parabolic troughs", Solar Energy, Vol. 64 Issue 1, pp. 115-120.

3. Arasu, A. Valan \& Sornakumar, T. (2007) "Design, manufacture and testing of fiberglass reinforced parabola trough for parabolic trough solar collectors”, Solar Energy, Vol. 81, pp. 1273-1279.

4. Fernandez-Garcia, E.Zarza, L. Valenzuela, M.Pervez, September 2010, "Parabola trough solar collectors and their applications” Science Direct, Elsevier, Renewable and sustainable Energy, Volume 14, Issue 7, pages 1695- 1721.

5. Mohd Rizwan, Md. Abdul Raheem Junaidi, Mohammad Suleman, Mohd. Aamer Hussain, October 2014, "Experimental verification And Analysis of Solar Parabolic Collector for water distillation” IJER, Vol no.3, Issue No.10, pp:588-593

6. Bakos, G. C., Ioannidis, I., Tsagas, N. F. \& Seftelis, I. (2001) “Design, optimization and conversion efficiency determination of a line-focus parabolic-trough solar-collector”, Applied Energy, Vol. 68, pp. 43-50.

7. Gharbia, Najla El, Derbalb, Halima, Bouaichaouia, Sofiane \& Said, Noureddine (2011) "A comparative study between parabolic trough collector and linear Fresnel reflector technologies”, Energy Procedia, Vol. 6, pp. 565-572.

8. Mayur G Tayade, R E Thombre, Subroto Dutt (2015) "Performance Evaluation of Solar parabolic trough" IJSRP, Vol no. 5, issue no. 1

9. Pradeep Kumar K V, Srinath T, Venkatesh Reddy, August (2013), "Design Fabrication and experimental testing of solar parabolic trough collectors with automated tracking mechanism”, IJRAME, vol no. 1, issue no.4, pp37-55.

10. Hamad, Faik Abdul Wahab (1988) "The performance of a cylindrical concentrator", Energy Conversion and Management, Vol. 28 Issue 3, pp. 251-256 
